\title{
Direct measurements of light attenuation by epiphytes on eelgrass Zostera marina
}

\author{
Mark J. Brush*, Scott W. Nixon \\ Graduate School of Oceanography, University of Rhode Island, Narragansett, Rhode Island 02882-1197, USA
}

\begin{abstract}
Declines in the seagrass Zostera marina L. in estuaries and lagoons have been attributed in part to reductions in irradiance reaching the seagrass blades. Epiphytes growing on $Z$. marina have the potential to attenuate a large fraction of the light that would otherwise reach the blades. This problem has previously been studied by measuring light penetration through homogenized epiphytic slurries or through glass slides fouled with epiphytes. However, the latter may not represent the natural succession or species composition found on live $Z$. marina leaves and the former does not preserve the structure of the epiphytic complex. Further, past studies have not measured attenuation across the full range of epiphytic densities found in the field. In this study, we measured light penetration across a wide range of epiphytic densities by holding scraped and unscraped $Z$. marina blades over a submerged light sensor. Results compared well with past studies at low epiphyte densities, with strong reductions in light penetration as density increased. However, at higher densities, penetration leveled off to a relatively constant value as the epiphytes floated out from the edges of the blade. Studies using slurries did not capture this phenomenon and thus predicted decreasing penetration down to $0 \%$.
\end{abstract}

KEY WORDS: Epiphytes $\cdot$ Light attenuation $\cdot$ Seagrass $\cdot$ Zostera marina

\section{INTRODUCTION}

The well-known and widespread decline of submersed aquatic angiosperms in shallow lakes and coastal marine waters around the world is commonly attributed, at least in part, to shading by excessive growths of epiphytes (e.g. Sand-Jensen 1977, Phillips et al. 1978, Borum \& Wium-Andersen 1980, Kemp et al. 1983, Orth \& Moore 1983, Twilley et al. 1985, Silberstein et al. 1986, Valiela et al. 1990, Neckles et al. 1993). The epiphytic community found on such plants is a heterogeneous and varying complex of bacteria, micro- and macroalgae, heterotrophic organisms, and organic and inorganic detritus and debris that is usually characterized in terms of total dry weight (DW), ash free dry weight (AFDW), and/or the weight of chlorophyll per unit area of leaf substrate. Because of the obvious potential for shading when the epiphytic

*E-mail: brush@vims.edu load is high, there have been repeated attempts to develop quantitative relationships between the weight of epiphytic material and the attenuation of photosynthetically active radiation (PAR) before it actually reaches the leaves of submersed plants (Table 1). Such relationships are a critical link in the formulation of numerical models of submersed plant growth (e.g. Wetzel \& Neckles 1986, Madden \& Kemp 1996, Fong et al. 1997, Buzzelli et al. 1998) and help to evaluate the relative importance of water-column turbidity and epiphyte load in reducing the amount of PAR reaching submersed plants (e.g. Sand-Jensen \& Søndergaard 1981).

Virtually all previous studies have used indirect approaches by which light attenuation has been measured as the light passed through an epiphyte matrix grown on artificial transparent substrates, or as the light passed through a suspension prepared from naturally occurring epiphytes removed from the leaves of various submersed plant species (Table 1). 


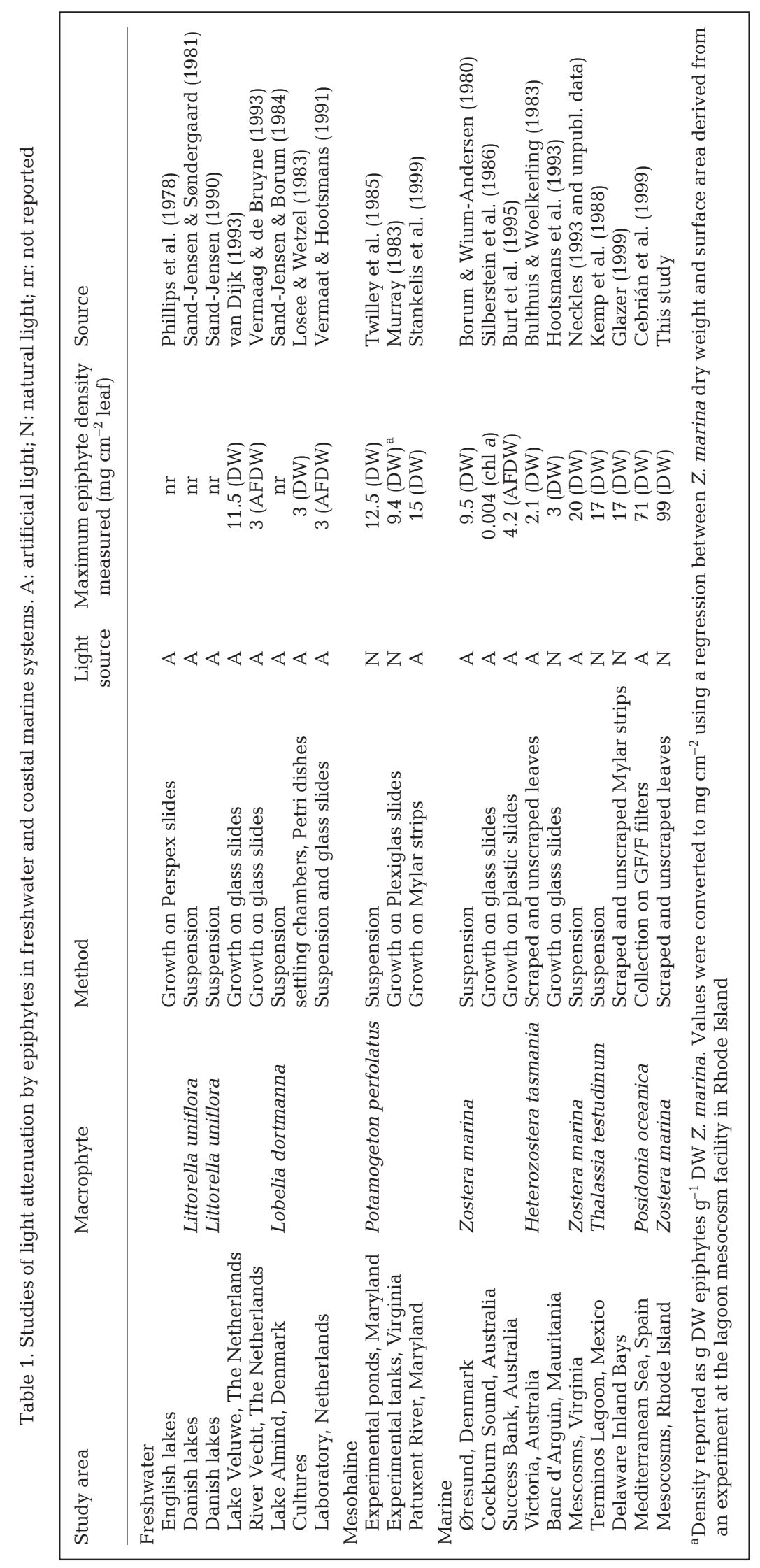

The only direct measurements of light attenuation by an intact epiphyte community growing on seagrass leaves appear to be those reported by Bulthuis \& Woelkerling (1983) for epiphytes growing on the seagrass Heterozostera tasmanica (Marteus ex Aschers) den Hartog in the Port Phillip Bay area of Australia. Their method involved measurements of light from a tungsten source as it passed through scraped and unscraped leaves placed on a microscope platform. Use of an artificial light source is common in epiphyte-attenuation studies (Table 1), and it may be less of a problem than it first appears. Neckles (1993) measured attenuation of $10 \mathrm{~nm}$ bands of PAR through slurries of epiphytic material from Zostera marina L. and found that although shorter wavelengths were attenuated faster than longer wavelengths, '... epiphytes attenuate light across the range of PAR with no window of high transmittance.' A more important limitation of the Bulthuis \& Woelkerling (1983) study is that the leaves they used had a maximum epiphyte cover of only a little over $2 \mathrm{mg}$ DW $\mathrm{cm}^{-2}$, while epiphyte cover on older leaves of the common temperate seagrass $Z$. marina may reach 50 to 100 mg DW cm ${ }^{-2}$ (e.g. Borum \& WiumAndersen 1980). It is also unclear if the leaves and epiphytes were fully submerged during the Bulthuis \& Woelkerling measurements.

Use of artificial seagrass leaves such as Mylar strips for light penetration measurements can be a useful alternative to using live seagrass (Stankelis et al. 1999), and such artificial substrates also make possible the measurement of light penetration through intact epiphyte communities. However, as with the Bulthuis \& Woelkerling (1983) study, the measurements conducted to date with artificial leaves have failed to cover the full range of epiphyte densities found in the field (Table 1). In fact, of the previous studies listed in Table 1, only that of Cebrián et al. (1999) measured penetration at densi-

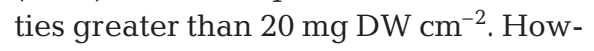
ever, their measurements were per- 
formed on epiphytic material which was collected on glass-fiber filters and thus, like the studies which used suspensions, did not reflect light penetration by an intact community. Further, Cebrián et al. (1999) measured transmission through epiphytic pigments only using a spectrophotometer, thereby excluding the effect of the inorganic fraction.

The issues of submersion and use of an intact epiphyte community are important because, as Losee and Wetzel (1983) so nicely put it, epiphytes form 'a complex optical system'. While relatively homogeneous slurries or suspensions of epiphyte material may conform to the Lambert-Beer relationship, the intact epiphyte community as it develops on natural leaves has an irregular and patchy architecture in which some light is absorbed, some is reflected, and some passes through. This structure is only manifest in intact communities under conditions of submersion, when the buoyancy of the various epiphytes can lift them away from the leaf surface. Our purpose here is to report the results of direct measurements of the attenuation of natural PAR as it passes through submersed, intact epiphyte communities across a wide range of densities that have developed on leaves of the eelgrass Zostera marina.

\section{MATERIALS AND METHODS}

We measured the attenuation of natural PAR by epiphytes using a $2 \pi$ underwater quantum sensor in an outdoor seawater bath, a similar quantum sensor in air, and a datalogger (LICOR LI-192SA, LI-190SA, and LI-1000, respectively). Blades of eelgrass with varying epiphytic loads were collected from plants growing in large tanks ( $4 \mathrm{~m}^{2} \times 1.1 \mathrm{~m}$ deep) at the Lagoon Mesocosm Facility at the University of Rhode Island (USA) and from Quonochontaug Pond, a nearby coastal lagoon, during August 1996, September 1997, and September 2000. Maximum development of epiphyte cover on eelgrass has taken place by late summer in this area (Lin et al. 1996). Descriptions of the mesocosm facility are given in Taylor et al. (1995) and Lin et al. (1996).

The epiphytes used in this study were dominated by 3 different communities. We did not obtain a precise taxonomic description of the epiphytes from 1996/97, but they were dominated by a green filamentous alga which we believe to be Ulothrix sp., with small amounts of Enteromorpha sp. and/or Cladophora sp. mixed in. This epiphytic community will subsequently be referred to as 'unidentified green'. We did obtain precise identifications of the epiphytes used in 2000, with one of the communities being dominated by Cladophora sp. and the other by Polysiphonia sp.
To measure light penetration, we scraped 1 side of each blade free of epiphytes and discarded the scraped material. Individual blades were then submersed over the underwater sensor with the scraped side facing down, so that the remaining epiphytes remained suspended away from the blade. We then recorded the fraction of natural incident irradiance (measured by the sensor in air) passing through both the blade and the remaining epiphytes at 1 to 3 places along the blade. The epiphytes on the other (upper) side of the blade were then scraped from an area of approximately 1 to $2.5 \mathrm{~cm}^{2}$ at each location of measurement along the blade, and the scraped material was saved for determination of dry weight per unit area. We replaced the epiphyte-free blade over the underwater sensor and measured the fraction of incident irradiance passing through the blade. Epiphyte-free blades attenuated $83 \pm 3 \%$ of incident light (mean $\pm \mathrm{SD}, \mathrm{n}=$ 69). The effect of scraping on blade optics was determined on 10 epiphyte-free blades by comparing percent transmission before and after scraping. Scraped blades transmitted an average of $0.93 \%$ less incident light than unscraped blades. Since our methods involved scraping the blade between measuring transmission through epiphytes intact on the blade and measuring transmission through the blade alone, all the latter data were increased by $0.93 \%$ to correct for the effect of scraping on blade optics.

We calculated the attenuation of light through the epiphytic material alone by normalizing the fraction of incident light passing through the epiphytes and blade to that passing through the epiphyte-free blade. Since transmission measurements were expressed relative to the incident irradiance through use of the quantum sensor in air, our method accounts for variability in irradiance between the unscraped and scraped readings. Further, both readings for a given plant were measured under the same type of light (i.e. direct or diffuse) to eliminate any error introduced by changes in light quality between readings (e.g. by passing clouds). Epiphyte density was determined by collecting the saved material onto pre-weighed Gelman A/E filters, drying at $60^{\circ} \mathrm{C}$, and dividing the dry weight by the area scraped (area of 1 side of the blade only).

\section{RESULTS AND DISCUSSION}

We obtained a total of 87 direct measurements of the attenuation of PAR by 3 epiphytic communities weighing as much as $99 \mathrm{mg} \mathrm{DW} \mathrm{cm}^{-2}$. This is a much wider range than previously examined (Table 1). Our results suggest that the attenuation of PAR as a function of intact epiphyte dry weight is well described by a negative hyperbolic equation (Fig. 1) of the form: 


$$
y=100-\mathrm{A}\left(\frac{x}{\mathrm{~B}+x}\right)
$$

where $y$ is the transmission (\%) of PAR incident on the epiphyte complex, $x$ is the DW density of epiphyte cover ( $\mathrm{mg} \mathrm{DW} \mathrm{cm}^{-2}$ ), and A and B are constants.

Past studies have frequently used an exponential decay function to describe epiphyte transmission. In the present study however, exponential decay functions, forced through $100 \%$ transmission at zero epiphyte biomass and fit to our observations, all gave lower $\mathrm{r}^{2}$ values, produced visibly inferior fits, and seriously underestimated attenuation at various levels of epiphyte biomass.

While the relationship between biomass and transmission was remarkably similar in Polysiphonia sp. and the unidentified species, Cladophora sp. transmitted substantially more light for a given biomass (Figs. 1 \& 2). This is consistent with the Cladophoradominated epiphytes being lighter in color and less densely arranged on the blades than the other 2 species.

With the exception of Cladophora sp., our observations agree with other models at very low epiphyte densities in showing a rapid increase in PAR attenuation with increasing epiphyte load (Fig. 2). An interesting exception is the study of Glazer (1999), who reported markedly greater PAR transmission for a given biomass and a linear rather than exponential relationship between the 2 variables. However, Glazer's epiphytic community was primarily composed of bryozoan colonies (B. Glazer pers. comm.), which are likely to have different optical properties than the algaldominated epiphytes surveyed in this and most of the previous studies. As with Cladophora sp. in the present study, it appears that the composition of the epiphytic community alters the relationship between biomass and attenuation.

Our negative hyperbolic function quickly diverges from most previous formulations as density increases (Fig. 2). As noted earlier, the only previous study using an intact epiphyte community on seagrass leaves made observations over a small range in density, and the linear regression provided for those data by Bulthuis \& Woelkerling (1983) diverges markedly from our observations above $\sim 5 \mathrm{mg} \mathrm{DW} \mathrm{cm}^{-2}$. While past studies generally predict PAR transmission as decreasing to $0 \%$ with increasing epiphytic cover, we found transmission to level off to a fairly constant percent of incident PAR as density increased. This limit to attenuation was dependent on the epiphytic community under study, with attenuation due to Cladophora sp. leveling off at approximately $70 \%$ of incident light and attenuation due to the other 2 communities leveling off at approximately 85 to $90 \%$ of incident light.

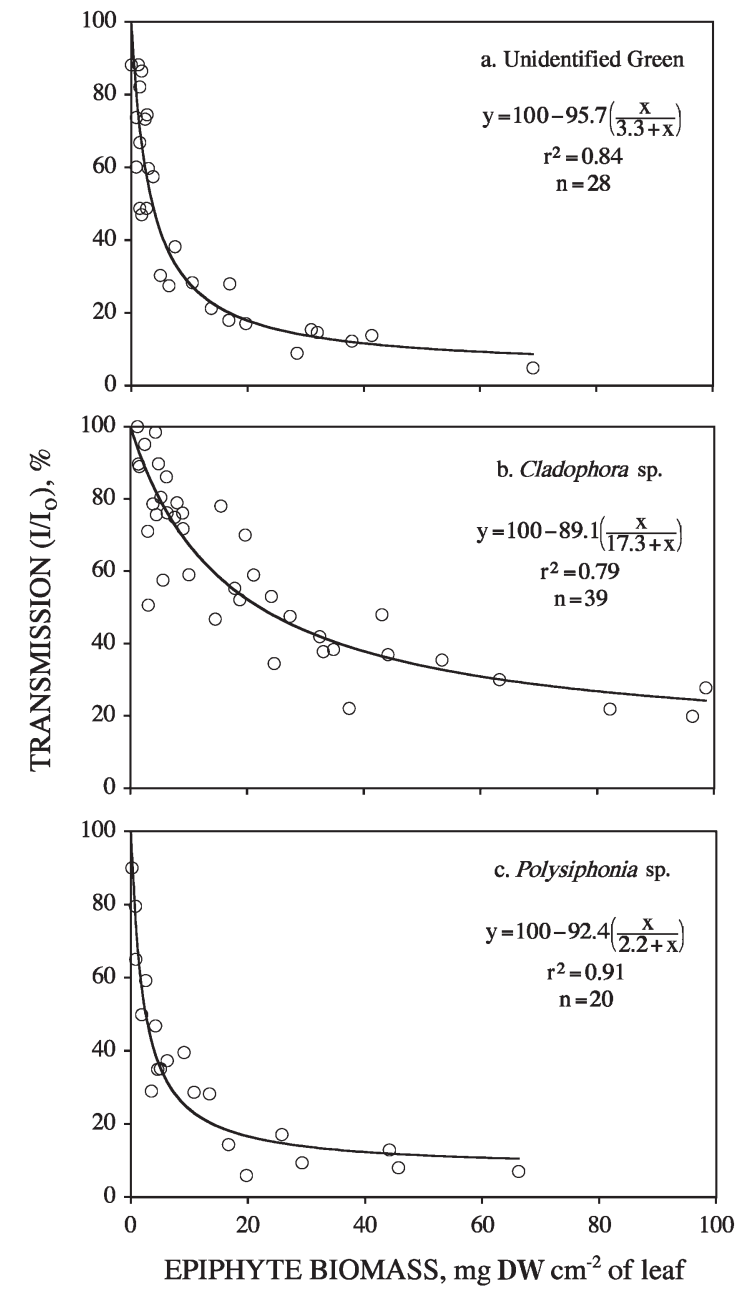

Fig. 1. Light transmission through epiphytes as a function of epiphytic density. Transmission expressed as percent irradiance incident to the epiphytic mass $\left(I_{0}\right)$ which passes through the bottom of the mass $(I)$; density expressed as epiphyte mass on 1 side of the blade per unit surface area of that side of the blade. Data points are individual measurements

The regressions of Murray (1983) and Stankelis et al. (1999) show a similar leveling off of transmission, but measurements were not made above a biomass of

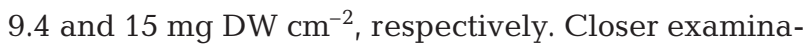
tion of the Stankelis et al. data (their Fig. 4-13b, p. 106) shows that their observations with diatom crusts actually tended towards $0 \%$ transmittance as epiphyte load increased, similar to the other exponential decay models in our Fig. 2 (R. M. Stankelis pers. comm.). The apparent leveling off at $15 \%$ transmission is an artifact of curve fitting, whereby the regression is heavily weighted by data at lower epiphyte densities.

At low epiphyte densities, the scatter in the observations in Fig. 2a,c is sufficiently great that any of the previously published models besides that of Glazer (1999) would adequately describe the data. However, 


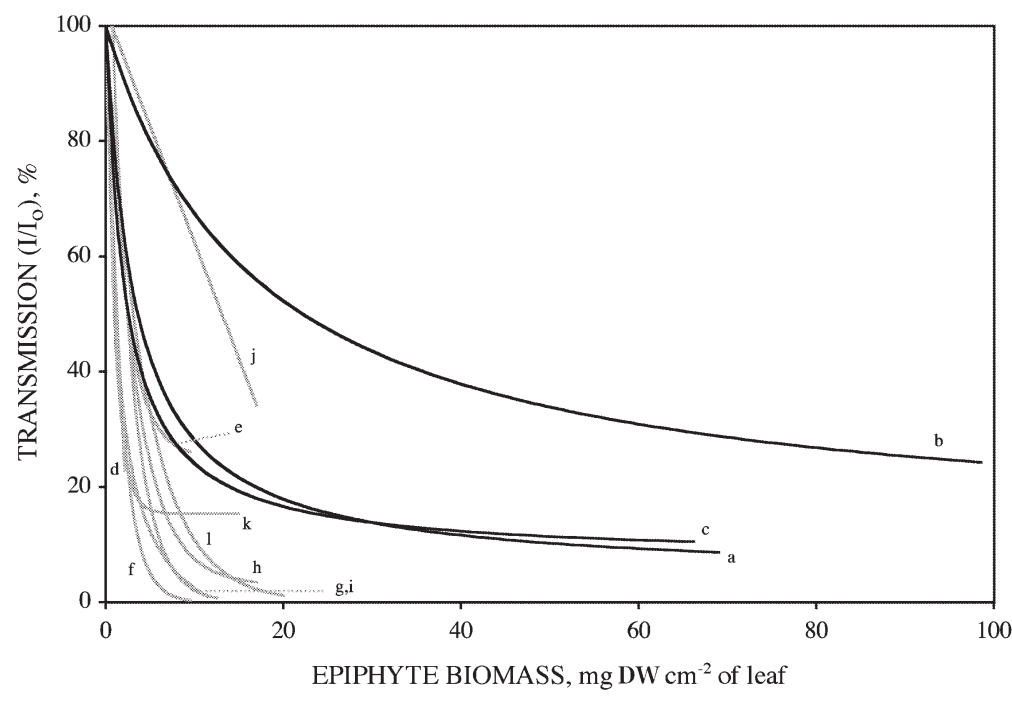

Fig. 2. Comparison of relationships between light transmssion and epiphyte density in this and previous studies. Regression lines for present study are black, and denoted as follows: a, unidentified green; b, Cladophora sp.; c, Polysiphornia sp. Regression lines for past studies are gray, and are denoted as follows: d, Bulthuis \& Woelkerling (1983); e, Murray (1983); f, Sand-Jensen \& Borum (1983); g, Twilley et al. (1985); h, Kemp et al. (1988); i, van Dijk (1993); j, Glazer (1990); k, Stankelis et al. (1999); l, Neckles (unpubl. data). Sand-Jensen \& Borum (1983) used the data of Broum \& Wium-Andersen (1980). Equations for Murray (1983) and Kemp et al. (1988) were estimated from graphs of their results. Regressions were plotted only across the range of epiphytic densities used in each study (see Table 1)

exact predictions of percent transmission by the various regressions at low epiphytic densities are markedly different (Table 2). The important result of this study is

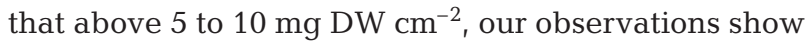
that PAR attenuation increases much more slowly with increasing epiphyte load (Fig. 2). We believe that this is due to a progression in the structural complexity of the epiphyte community. Over $25 \mathrm{yr}$ ago, a detailed microscopic study of 'fouling' on eelgrass in Rhode Island (Sieburth \& Thomas 1973) showed that the leaves are first colonized by a 'crust' composed of the diatom Cocconeis scutellum (Meunier) and assorted detrital particles. Once the crust is formed, the leaves are further colonized by a heterogeneous and varied assortment of other organisms. Brown (1962), Hargraves (1965), and Lin (1995) have provided detailed descriptions for Rhode Island and the lagoon mesocosm facility. These organisms are attached in various ways to the C. scutellum crust (e.g. diatoms, bacteria) or directly to the leaves (e.g. Cladophora sp., Polysiphonia sp.), and as these larger algal species grow, many can be seen to float out from the leaf. As epiphyte mass increases, much of this additional material either floats or grows out to the sides rather than accumulating directly above the leaf. This additional material therefore makes little if any further contribution to
PAR attenuation. As a result, attenuation levels off with increasing density, as found in this study (Figs. $1 \& 2$ ).

We observed this pattern of growth in the 3 epiphytic communities used in this study (Fig. 3). Our measurements were made on leaves of varying age developed over 3 summers under a range of nutrient loading conditions. The results are sufficiently consistent to suggest that epiphytic attenuation cannot simply be modeled with a biomass-specific attenuation coefficient, because the architecture of the epiphytes plays a role in determining the shape of the biomass-transmission relationship. Our hyperbolic expression which levels off with increasing density therefore provides a better fit to our data than an exponential decay function.

Our results further illustrate that the shape of the biomass-transmission relationship is dependent on the type of epiphytes present, with transmission through Cladophora sp. being much greater for a given biomass than in our 2 more densely arranged epiphyte communities (Figs. 1 \& 2). This is further evidenced by the results of Glazer (1999), who found much higher transmission through epiphyte communities dominated by bryozoans (Fig. 2). Furthermore, Cebrián et al. (1999) found that light was absorbed more quickly by red encrusting epiphytes than by brown erect algae, which would presumably be able to float out to the sides of the blades at higher densities.

While our negative hyperbolic relationship should generally apply to filamentous epiphytes, it is possible

Table 2. Range in predicted percent transmission $\left(I / I_{0}, \%\right)$ at low epiphytic densities by regression models in Figs. 1 \& 2

\begin{tabular}{|c|c|c|c|c|c|}
\hline \multirow[t]{2}{*}{ Source } & \multicolumn{5}{|c|}{ piphyte density $\left(\mathrm{mg} \mathrm{DW} \mathrm{cm}^{-2}\right.$ ) } \\
\hline & 1 & 2 & 3 & 5 & 10 \\
\hline Bulthuis \& Woelkerling (1983) & 59 & 26 & $0^{\mathrm{a}}$ & $0^{\mathrm{a}}$ & $0^{\mathrm{a}}$ \\
\hline Murray (1983) & 73 & 55 & 44 & 33 & $26^{\mathrm{a}}$ \\
\hline Sand-Jensen \& Borum (1983) & 55 & 30 & 17 & 5 & $0^{\mathrm{a}}$ \\
\hline Twilley et al. (1985) & 90 & 59 & 39 & 17 & 2 \\
\hline Kemp et al. (1988) & 76 & 57 & 42 & 24 & 8 \\
\hline van Dijk (1993) & 52 & 33 & 23 & 12 & 2 \\
\hline Glazer (1999) & 99 & 95 & 91 & 83 & 62 \\
\hline Stankelis et al. (1999) & 48 & 28 & 20 & 16 & 15 \\
\hline Neckles (unpubl. data) & 80 & 64 & 51 & 33 & 11 \\
\hline This study, unidentified green & 78 & 64 & 55 & 42 & 28 \\
\hline This study, Cladophora sp. & 95 & 91 & 87 & 80 & 67 \\
\hline This study, Polysiphonia sp. & 71 & 56 & 46 & 36 & 24 \\
\hline
\end{tabular}




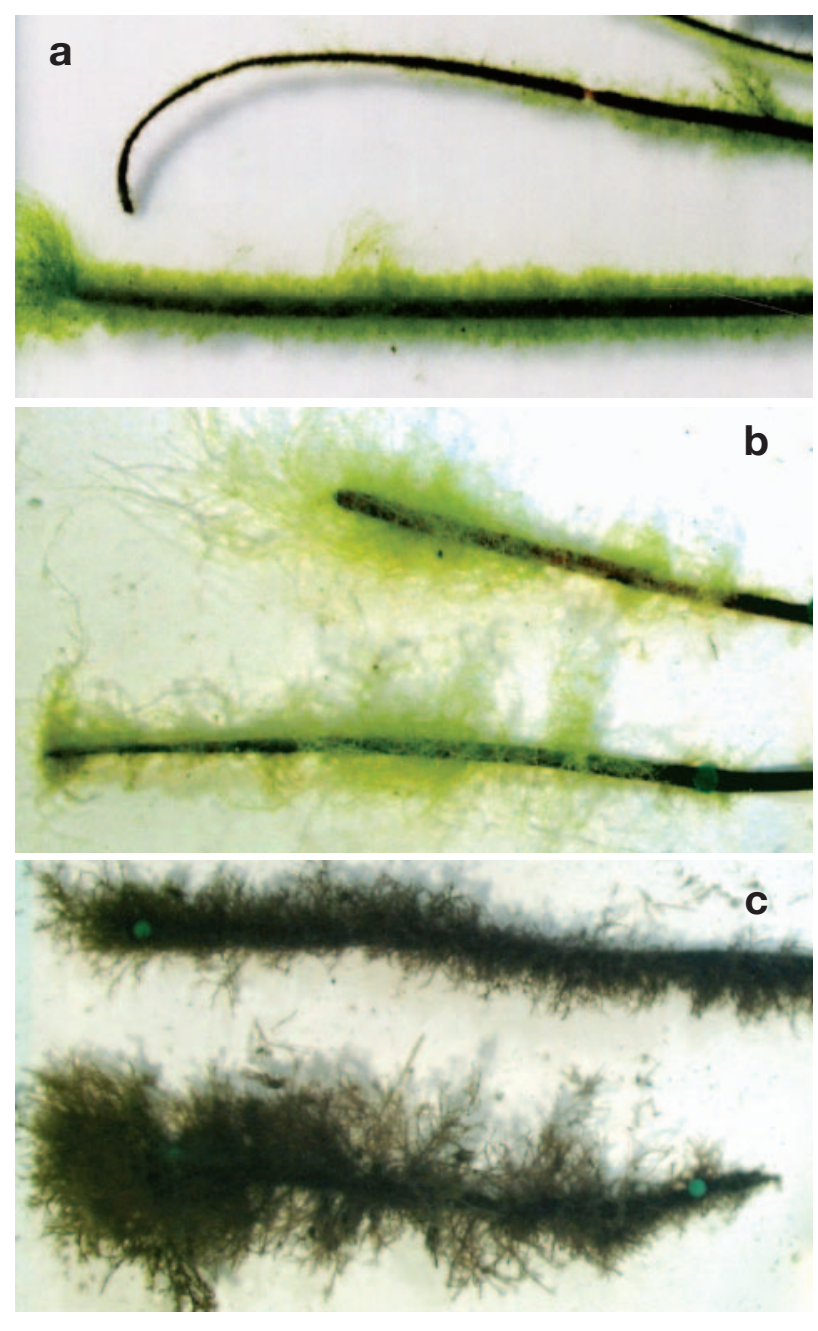

Fig. 3. Photographs of the 3 epiphytes used in this study. (a) Unidentified green; (b) Cladophora sp.; (c) Polysiphonia sp. Epiphytes were photographed while intact on Zostera marina, and can be seen floating or growing out to the sides of the blades

that linear or exponential decay models would be more appropriate for epiphytes that do not float out from seagrass blades, such as diatoms, bryozoans, or encrusting coralline red algae. It should also be noted that our technique of using intact epiphyte communities growing on natural seagrass blades may not be readily applicable in studies of encrusting epiphytes such as bryozoans or coralline algae. It may be impossible to remove these epiphytes from natural seagrass blades by scraping. In these cases, use of fouled and control mylar strips or similar artificial seagrass mimics may be a useful alternative to natural blades. Further, such artificial mimics transmit more light than natural blades, and thus would be a useful alternative for species which attenuate substantially more light than Zostera marina.
Some (perhaps much) attenuation through the understory must also be due to the highly variable inorganic fraction of the epiphyte matrix (Lin 1995), although Losee \& Wetzel (1983) reported that diatom frustules are more important in light-scattering than absorption. Late-summer epiphytic material from the lagoon mesocosms used in this work commonly contains 20 to $35 \%$ organic matter (AFDW), a range similar to the material found on Zostera marina in Chesapeake Bay $(\mathrm{H}$. Neckles pers. comm.).

Our results confirm the importance of capturing the submerged structure of the epiphyte community as closely as possible when obtaining measures of light attenuation, as well as measuring attenuation across the full range of epiphyte densities found in the field. Our results also show that the most dramatic impact of epiphyte cover in reducing the amount of PAR reaching seagrass leaves may come at relatively low epiphyte densities. It is not necessary for the epiphyte cover to be conspicuous before it has a major impact on light reduction in a macrophyte canopy. Nevertheless, there appears to be an upper limit to epiphytic light attenuation beyond which little additional light is absorbed despite increases in epiphytic load, at least in filamentous growth forms. Such an upper limit could result in high seagrass productivity despite high epiphytic loading.

Acknowledgements. Funding for this research was provided by the Rhode Island Sea Grant College Program, NOAA. We thank H. Neckles, R. Stankelis, B. Glazer, J. Vermaat, and E. Bailey for providing data, published materials, and helpful comments. We are grateful to P. Hargraves and M. VillalardBohnsack for assistance with epiphyte identification.

\section{LITERATURE CITED}

Borum J, Wium-Andersen S (1980) Biomass and production of epiphytes on eelgrass (Zostera marina L.) in the Øresund, Denmark. Ophelia (Suppl 1):57-64

Brown CL (1962) On the ecology of Aufwuchs of Zostera marina in Charlestown Pond, RI. MS thesis, University of Rhode Island, Kingston, RI

Bulthuis DA, Woelkerling WJ (1983) Biomass accumulation and shading effects of epiphytes on leaves of the seagrass, Heterozostera tasmanica, in Victoria, Australia. Aquat Bot 16:137-148

Burt JS, Kendrick GA, Masini RJ, Simpson CJ (1995) Light and Posidonia sinuosa seagrass meadows in the temperate coastal waters of Western Australia. II. Effect of epiphyte species assemblage and biomass on attenuating light to the leaf surface. Contribution to the Southern Metropolitan Coastal Waters Study (1991-1994), Department of Environmental Protection, Perth, Western Australia

Buzzelli CP, Wetzel RL, Meyers MB (1998) Dynamic simulation of littoral zone habitats in lower Chesapeake Bay. II. Seagrass habitat primary production and water quality relationships. Estuaries 21(4B):673-689

Cebrián J, Enríquez S, Fortes M, Agawin N, Vermaat JE, 
Duarte CM (1999) Epiphyte accrual on Posidonia oceanica (L.) Delile leaves: implications for light absorption. Bot Mar 42:123-128

Fong P, Jacobson ME, Mescher MC, Lirman D, Harwell MC (1997) Investigating the management potential of a seagrass model through sensitivity analysis and experiments. Ecol Appl 7:300-315

Glazer BT (1999) Analysis of physical, chemical, and biological factors inhibiting growth and restoration of submerged vascular plants in Delaware's Indian River and Rehoboth Bays. MS thesis, University of Delaware, Lewes, DE

Hargraves PE (1965) On the seasonal changes in plant periphyton in a salinity gradient. MS thesis, University of Rhode Island, Kingston, RI

Hootsmans MJM, Vermaat JE, Beijer JAJ (1993) Periphyton density and shading in relation to tidal depth and fiddler crab activity in intertidal seagrass beds of the Banc d'Arguin (Mauritania). Hydrobiologia 258:73-80

Kemp WM, Twilley RR, Stevenson JC, Boynton WR, Means JC (1983) The decline of submerged vascular plants in upper Chesapeake Bay: summary of results concerning possible causes. Mar Technol Soc J 17:78-89

Kemp WM, Boynton WR, Murray L, Madden CJ, Wetzel RL, Vera Herrera F (1988) Light relations for the seagrass Thalassia testudinum, and its epiphytic algae in a tropical estuarine environment. In: Yanez-Arancibia A, Day JW Jr (eds) Ecology of coastal ecosystems in the southern Gulf of Mexico: the Terminos Lagoon Region. Instituto Ciencias del Mar y Limnología, Universidad Nacional Autónoma de Mexico, Coastal Ecology Institute, Louisiana State University, Editorial Universitaria, México DF, p 193-206

Lin HJ (1995) Responses of epiphytes on eelgrass (Zostera marina L.) to nutrient enrichment. $\mathrm{PhD}$ thesis, University of Rhode Island, Kingston, RI

Lin HJ, Nixon SW, Taylor DI, Granger SL, Buckley BA (1996) Responses of epiphytes on eelgrass, Zostera marina L., to separate and combined nitrogen and phosphorus enrichment. Aquat Bot 52:243-258

Losee RF, Wetzel RG (1983) Selective light attenuation by the periphyton complex. In: Wetzel RG (ed) Periphyton of fresh water ecosystems. Dr W. Junk Publishers, The Hague, p 89-96

Madden CJ, Kemp WM (1996) Ecosystem model of an estuarine submersed plant community: calibration and simulation of eutrophication responses. Estuaries 19(2B): 457-474

Murray L (1983) Metabolic and structural studies of several temperate seagrass communities, with emphasis on microalgal components. PhD thesis, College of William and Mary, Williamsburg, VA

Neckles HA (1993) The role of epiphytes in seagrass production and survival: microcosm studies and simulation modeling. In: Morris LJ, Tomasko DA (eds) Proceedings and conclusions of workshops on submerged aquatic vegetation initiative and photosynthetically active radiation. Special publication SJ93-SP13, Indian River Lagoon National Estuary Program, Melbourne, Florida and St. Johns River Water Management District, Palatka, FL, p 91-105

Neckles HA, Wetzel RL, Orth RJ (1993) Relative effects of nutrient enrichment and grazing on epiphyte-macrophyte (Zostera marina L.) dynamics. Oecologia 93:285-295

Orth RJ, Moore KA (1983) Chesapeake Bay: an unprece- dented decline in submerged aquatic vegetation. Science 222:51-53

Phillips GL, Eminson D, Moss B (1978) A mechanism to account for macrophyte decline in progressively eutrophicated freshwaters. Aquat Bot 4:103-126

Sand-Jensen K (1977) Effect of epiphytes on eelgrass photosynthesis. Aquat Bot 3:55-63

Sand-Jensen K (1990) Epiphyte shading: its role in resulting depth distribution of submerged aquatic macrophytes. Folia Geobot Phytotaxon 25:315-320

Sand-Jensen K, Borum J (1983) Regulation of growth of eelgrass (Zostera marina L.) in Danish coastal waters. Mar Technol Soc J 17:15-21

Sand-Jensen K, Borum J (1984) Epiphyte shading and its effect on photosynthesis and diel metabolism of Lobelia dortmanna L. during the spring bloom in a Danish lake. Aquat Bot 20:109-119

Sand-Jensen K, Søndergaard M (1981) Phytoplankton and epiphyte development and their shading effect on submerged macrophytes in lakes of different nutrient status. Int Rev Gesamten Hydrobiol 66:529-552

Sieburth JMcN, Thomas CD (1973) Fouling on eelgrass (Zostera marina L.). J Phycol 9:46-50

Silberstein K, Chiffings AW, McComb AJ (1986) The loss of seagrass in Cockburn Sound, Western Australia. III. The effect of epiphytes on productivity of Posidonia australis Hook. F. Aquat Bot 24:355-371

Stankelis RM, Boynton WR, Frank JM (1999) Submerged aquatic vegetation (SAV) habitat evaluation. In: Ecosystems processes component level 1 interpretive report no 16. Chesapeake Biological Laboratory, University of Maryland System, Solomons, MD, p 77-118

Taylor DI, Nixon SW, Granger SL, Buckley BA, McMahon JP, Lin HJ (1995) Responses of coastal lagoon plant communities to different forms of nutrient enrichment-a mesocosm experiment. Aquat Bot 52:19-34

Twilley RR, Kemp WM, Staver KW, Stevenson JC, Boynton WR (1985) Nutrient enrichment of estuarine submersed vascular plant communities. I. Algal growth and effects on production of plants and associated communities. Mar Ecol Prog Ser 23:179-191

Valiela I, Costa J, Foreman K, Teal JM, Howes B, Aubrey D (1990) Transport of groundwater-borne nutrients from watersheds and their effects on coastal waters. Biogeochemistry 10:177-197

van Dijk GM (1993) Dynamics and attenuation characteristics of periphyton upon artificial substratum under various light conditions and some additional observations on periphyton upon Potamogeton pectinatus L. Hydrobiologia 252:143-161

Vermaat JE, de Bruyne RJ (1993) Factors limiting the distribution of submerged waterplants in the lowland River Vecht (The Netherlands). Freshw Biol 30:147-157

Vermaat JE, Hootsmans MJM (1991) Periphyton dynamics in a temperature-light gradient. In: Hootsmans MJM, Vermaat JE (eds) Macrophytes, a key to understanding changes caused by eutrophication in shallow freshwater ecosystems. International Institute for Infrastructural Hydraulic and Environmental Engineering (IHE) Report Series 21, IHE, Delft, p 159-187

Wetzel RL, Neckles HA (1986) A model of Zostera marina L. photosynthesis and growth: simulated effects of selected physical-chemical variables and biological interactions. Aquat Bot 26:307-323

Submitted: October 1, 2000; Accepted: May 14, 2001

Proofs received from author(s): July 23, 2002 